\title{
A internet vai à escola: domínio e apropriação de ferramentas culturais*
}

Marcelo Giordan

Universidade de São Paulo

\section{Resumo}

0 objetivo deste artigo é descrever e analisar o processo de introdução da internet em uma comunidade escolar, e verificar como o domínio e a apropriação da ferramenta cultural e os propósitos da ação mediada condicionam esse processo. A partir da descrição e análise desse processo, identificam-se os elementos condicionantes do domínio e da apropriação das ferramentas culturais, tendo como suposto o conceito de ambientes telemáticos. Definem-se ambientes da internet a partir do conceito de ferramenta cultural e das propriedades da ação mediada. Descreve-se a introdução da internet em uma escola no curso de um programa de formação continuada, de onde se obtêm evidências da determinação dos propósitos e das formas de uso da ferramenta cultural pelos agentes sobre os processos de elaboração de significados, e de apropriação do correio eletrônico pelos professores e pela instituição. Analisam-se as modalidades discursivas observadas nos diálogos para explicar as ações internas e externas realizadas pelos professores, a partir das quais se discute a interação entre a estrutura discursiva e a estrutura das ações mediadas, bem como as funções do diálogo e da ferramenta cultural na elaboração de significados. Apresentam-se razões para se realizarem programas de formação continuada sobre o uso da internet, no interior da escola, justificadas pelas transformações observadas na ambiência de ensino e aprendizagem.

\section{Palavras-chave:}

Ação mediada - Discurso - Formação continuada - Internet.

* Agradeço o auxílio financeiro, processo 99/01817, dado pela Fapesp para a realização deste trabalho e à Capes, pela bolsa de pós-douramento, processo 0309-02-8. 


\title{
The Internet goes to school: mastery and incorporation of cultural tools
}

\author{
Marcelo Giordan \\ Universidade de São Paulo
}

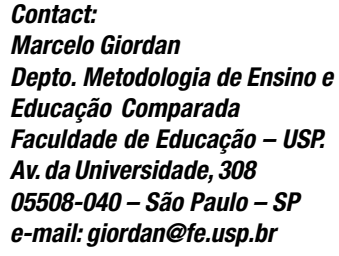

*The author wish to thank the financial support to this study from FAPESP (n.99/01817) and Capes (0309-02-8).

\begin{abstract}
The objective of this article is to describe and analyze the process of introduction of the Internet in a school community, and to observe how the mastery and incorporation of the cultural tool and the purposes of the mediated action intervene in that process. From the description and analysis of the process, the elements intervening in the mastery and incorporation of the cultural tools are identified, based on the concept of telematic environments. Internet environments are defined based on the concept of cultural tool, and from the properties of mediated action. The introduction of the Internet at a school in a continuing education course is described, whence evidence is obtained of the preponderance of the purposes and manners of use of the cultural tool by the agents over the processes of creation of meanings, and of the incorporation of electronic mail by teachers and institution. The discursive modes observed in the dialogues are analyzed to explain teachers' internal and external actions, from which a discussion is made about the interaction between discursive structure and structure of mediated actions, as well as on the functions of the dialogue and of the cultural tool in the production of meanings. Reasons are presented for the provision of programs of continuing education on the use of the Internet within schools, justified by the transformations observed in the teaching and learning milieu.
\end{abstract}

\section{Keywords}

Mediated action - Discourse - School - Continuing education Internet. 


\section{Da teoria da ação mediada}

A idéia de ação mediada que trazemos para este artigo inspira-se nos estudos de James Wertsch, discutidas em seu livro Mind as Action (1998). Vinculado à tradição sociocultural, o autor apóia-se em estudiosos como Vygotsky para tratar do processo de internalização, Bakhtin para discutir dialogia e gêneros de discurso, e principalmente em Kenneth Burke, para focar sobre as múltiplas perspectivas da ação humana.

Wertsch vai buscar em Burke sua abordagem para analisar a ação humana, que este desenvolveu para descrever o dramatismo. $\mathrm{Na}$ análise das ações humanas sob enfoques disciplinares, Burke sugere a existência de duas categorias de perguntas, uma de natureza ontológica e outra de natureza metodológica (Burke, 1973). Tais análises costumam se ater a um determinado elemento constituidor da ação humana, que representa o objeto de estudo em uma perspectiva disciplinar. Burke propõe um total de cinco elementos que formam o pentagrama das telas terminísticas (Figura 1), por meio das quais os estudos disciplinares analisam fragmentos da ação. Assim, o estudo da ação humana sob uma determinada perspectiva analítica se orienta por uma dada janela terminística e por sua terminologia, que selecionam fragmentos parciais da realidade.

Burke critica essa conduta analítica de focar a realidade por meio de telas terminísticas disciplinares, e sugere uma abordagem que seja capaz de vincular as perspectivas, sem reduzilas, umas às outras (Wertsch, 1998). Essa abordagem está expressa na conduta metodológica de tratar os elementos do pentagrama como construtos hipotéticos, considerando suas possibilidades de transformação e faixas de combinação e então analisar como esses construtos podem explicar as ações humanas (Burke, 1969), o que implica rejeitá-los como simples reflexos da realidade. Nesse sentido, a investigação da ação humana passaria a ser conduzida por uma ferramenta, o pentagrama, que ao vincular os cinco elementos permitiria uma análise multifocada e integrada da ação humana e de seus motivos.

Figura 1. Pentagrama das telas terminísticas da ação humana. (adaptado de Burke, 1969, p. xv; 1973, p. 68).

\begin{tabular}{|l|l|l|}
\hline Elemento & \multicolumn{1}{|c|}{ Pergunta } & Natureza da pergunta \\
\hline Ato & 0 que foi feito? & Ontológica \\
\hline Propósito & Por que foi feito? & Ontológica \\
\hline Agente & Quem fez? & Metodológica \\
\hline Agência & Como ele fez? & Metodológica \\
\hline Cena & Quando e onde foi feito? & Metodológica \\
\hline
\end{tabular}

Certamente, a complexidade dessa análise multifocada poderia inviabilizar o estudo com o risco de torná-lo superficial e relativista. É nesse sentido que o enfoque na ação mediada torna-se atrativo, pois ao considerarmos a tensão agentes-agindo-com-ferramentas-culturais (agências na designação de Burke) como unidade de análise, podemos nos manter comprometidos com o princípio de investigar a ação, situando-a em seu contexto cultural e institucional. Para tanto, é preciso reconhecer que a tensão irredutível "agentes-ferramentas culturais" pode ser representativa da ação mediada, e pode, portanto, ser adotada como uma unidade de análise capaz de explicar satisfatoriamente ações humanas diversificadas, como por exemplo, aquelas que se realizam na escola. Sob esta perspectiva, para saber quem executa a ação ou quem fala em um diálogo é preciso considerar não apenas o sujeito isolado, mas também o meio mediacional que ele emprega para agir ou falar. É diante da indissociabilidade entre agente e ferramenta cultural que passamos a considerar como ocorre a elaboração de significados pelos agentes, e como a comunidade escolar domina e se apropria de tecnologias da comunicação e informação, reconhecendo que tanto elaboração de significados como apropriação de ferramentas culturais são processos acoplados que podem ser explicados na perspectiva da ação mediada.

Para tratar da elaboração de significados consideramos incompleto o conceito de internalização, especificamente por suscitar a oposição entre processos internos e externos, o 
que rejeitamos em prol de uma relação de acoplamento entre ações internas e externas realizadas por agentes em uníssono com as ferramentas culturais. Ao considerar a idéia de zona de desenvolvimento proximal (ZDP), Bruner menciona ter identificado uma possivel contradição no pensamento de Vygotsky. Tratando a ZDP sobre consciência e controle, Bruner pergunta como poderia o aprendizado antecipar-se ao desenvolvimento, se consciência e controle são adquiridos após a função ter sido espontaneamente internalizada? Bruner resolve a contradição aparente, observando que a ZDP está correlacionada à aquisição e ao controle consciente de uma função qualquer, controle esse que só se manifestará no aprendiz quando a função alcançar o status de ferramenta. Antes disso, o tutor servirá ao aprendiz como forma indireta de consciência ou estará compartilhando com ele a ferramenta capaz de controlar a ação (Bruner, 1985). Bruner evoca a noção de "andaimes" para se referir a esse papel do tutor, conceito desenvolvido em um trabalho seminal sobre o papel da tutoria na resolução de problemas (Wood; Bruner; Ross, 1976).

Nesse sentido, consideramos que as noções de domínio como "saber usar a ferramenta cultural” (Wertsch, 1998, p. 50) e apropriação como "tomar algo do outro e torná-lo seu próprio” (p. 53) são mais adequadas para explicar o processo de elaboração de significados pelos indivíduos, por meio de ações internas e externas mediadas por ferramentas culturais. No caso do presente estudo, consideramos que essas ações estão acopladas ao processo de apropriação da internet pela escola. Portanto, é pela análise comparativa das ações executadas pelos professores no curso de um programa de formação continuada, por meio de um programa de tutoria envolvendo professores, tutores e estudo-dirigido, que iremos buscar elementos para explicar dois processos, um de natureza sociocognitiva e outro de natureza sociocultural. Desta maneira, nosso problema reside em explicar como o domínio e a apropriação de ferra- mentas culturais sustentam a elaboração de significados por professores agindo nos planos intra e intermental, como essas ações são orientadas por um programa de formação continuada, e como elas orientam a introdução da internet nas práticas escolares.

Assim como na abordagem vygotskiana, a teoria da ação mediada concebe os sistemas semióticos como determinantes do processo de elaboração de significados, por reconhecer neles uma construção eminentemente humana desenvolvida no curso das histórias da espécie, da sociedade, do sujeito e da própria ação. Dentre esses sistemas, a linguagem verbal se destaca, pois é pela mediação da oralidade e da escrita que ocorrem não apenas a maioria, mas também as principais e mais significativas ações humanas. É tomando por base a centralidade da linguagem verbal nas ações humanas que as idéias de Bakhtin a respeito de dialogia e gênero de discurso são incorporadas ao quadro epistemológico da ação mediada.

Ao discutir os principais conceitos da teoria dialógica de Bakhtin, Wertsch observa que a heteroglossia, a apropriação das palavras do outro, é condicionadora da significação em qualquer ato de fala. Para Bakhtin,

\section{a linguagem não é um sistema abstrato de formas normativas, mas sim uma concep- ção heteroglóssica concreta do mundo. Toda a palavra tem o "sabor" de uma pro- fissão, um gênero, uma tendência, um par- tido, um trabalho particular, uma pessoa particular, uma geração, uma faixa etária, o dia e hora. (apud Wertsch 1998, p. 77)}

Bakhtin nos fornece a exata dimensão da centralidade da heteroglossia no processo de elaboração de significados ao tratar a forma e a função dos esquemas enunciativos do discurso citado como elementos determinantes da apreensão ativa e apreciativa da enunciação do outro. Se, no limite, a enunciação é produto das vozes que habitam o interior do discurso, forma e função da enunciação devem exercer in- 
fluência reguladora sobre os processos internos de elaboração de significados, pois,

aquele que apreende a enunciação de outrem não é um ser mudo, privado de palavra, mas ao contrário um ser cheio de palavras interiores. Toda a sua atividade mental, o que se pode chamar o "fundo perceptivo", é mediatizado para ele pelo discurso interior e é por aí que se opera a junção com o discurso apreendido do exterior. (Voloshinov, 1997, p. 147)

Se a compreensão é forjada no discurso interior, seu elo com o discurso do outro se encontra na unidade de apreensão ativa, formada pelo comentário efetivo e pela réplica interior, duas operações que só podem ser isoladas para fins analíticos. É, portanto, na análise das locuções, que habitam tanto o discurso interior quanto o exterior, que iremos buscar evidências da apropriação de formas e funções discursivas particulares. Para além do conteúdo e das formas do discurso, é necessário estender o foco de análise para as situações nas quais os agentes executam as ações, sejam elas efetuadas no plano da conversação, ou no uso do computador, que é o novo instrumento de mediação responsável pela enunciação de outras vozes. Dessa maneira, reconhecemos a natureza situada tanto da elaboração de significados quanto dos atos de fala e indicamos que a constituição do cenário, uma das janelas terminísticas, conta agora com a presença de um meio propag-ador de outros sistemas semióticos, que o faz por meio de uma ambiência típica.

Devemos ainda considerar, para fins de compreensão do processo de elaboração de significados, a proposição do dualismo funcional sugerida por Lotman para explicar o entrelaçamento de textos em um sistema cultural (Lotman, 1988). Para o autor, todo texto cumpre pelo menos duas funções: expressar significados e gerar novos significados. Tomando a locução como caso particular de texto, assim como Lotman o faz, admite-se que para cumprir a primeira função será necessário que as locuções tenham um grau máximo de univocalidade. Da mesma forma, deve-se considerar a heterogeneidade interna como uma propriedade das locuções, cuja função é gerar novos significados. Ao discutir a noção de dualismo funcional à luz da dialogicidade e da autoridade das locuções, apontadas por Bakhtin, Wertsch sugere que as locuções podem cumprir essas duas funções, o que implica reconhecer uma tensão dinâmica entre ambas (1991, p. 79). É essa tensão que buscaremos identificar nos diálogos para verificar como ocorrem as ações de elaboração de significados.

\section{Da ambiência da internet}

Poucas pessoas percebem as inúmeras interfaces acionadas cada vez que acessam a internet, sejam elas "duras" ou "macias". Boa parte dos usuários dispensa o teclado em seus acessos, pois muitos já têm organizado um caderno de endereços favoritos e executam os comandos a partir do mouse. Mas é sem dúvida a tela que mobiliza maior atenção e dirige as ações dos internautas. Essas três interfaces são as de maior visibilidade entre as interfaces duras que fazem parte do cenário de ações do internauta. Elas mediam operações básicas como a execução de comandos, os quais ocupam o primeiro nível de uma série de interfaces macias, ou aplicações. Aquém dos comandos, estão as aplicações de nosso objeto de interesse, quais sejam, aquelas responsáveis pela formação de uma ambiência telemática, em meio a qual os internautas executam ações mediadas por ferramentas culturais.

Como a atenção do agente está focada na tela e nos objetos icônicos, imagéticos e textuais que nela se apresentam, quando não nos efeitos sonoros provenientes das caixas de som, a maior parte das aplicações permanece submersa e fora de seu controle, o que é benéfico à primeira vista, pois permite que os propósitos das ações sejam orientados pelo agente, em combinação com co-agentes e com 
as ferramentas culturais. Apesar do benefício, em muitas situações as mudanças ocorridas na ambiência não são perceptíveis, quando, por exemplo, a ação provoca mudança de tela ou alterações no interior da própria tela.

Uma das razões que nos fazem considerar a necessidade de apurar o conceito de ferramenta cultural são os efeitos sobre a ação mediada provocados pela combinação de várias camadas de interfaces, particularmente sobre os propósitos dos agentes e sua repercussão sobre o domínio e a apropriação da ferramenta cultural. No entanto, a principal razão para reelaborarmos a noção de ferramenta cultural à luz da teoria da ação mediada é a própria natureza das ações realizadas em um espaço desterritorializado e virtual. Seguramente a desterritorialização e a virtualidade da internet alteram radicalmente a natureza das ações humanas, principalmente por serem decorrentes de uma combinação inusitada de propriedades e funções das ferramentas culturais. Tendo em vista que essa proposta de reelaboração se dá no âmbito dos objetivos de investigar os efeitos da apropriação da internet pela escola, iremos considerar apenas as ações mediadas com efeitos diretos sobre o contexto escolar, quais sejam, comunicar, informar, simular, publicar, e ensinar e aprender.

Primeiramente é preciso reafirmar que a ferramenta cultural só pode ser considerada enquanto tal, quando o agente dela faz uso para executar uma ação, o que Wertsch chamou de tensão irredutível agente - ferramenta cultural (1998, p. 25). Dessa maneira, durante a edição de uma mensagem é a ferramenta cultural correio eletrônico que está em uso, assim como durante a seleção, organização e leitura das mensagens, o agente executa essas ações com a mesma ferramenta cultural. Para cada uma das ações, o correio eletrônico atende a propósitos distintos, que na maior parte das vezes estão subordinados a um propósito hierarquicamente superior, como por exemplo enviar uma correspondência, o que não é realizado pela díade agente-ferramenta cultural, mas sim por uma aplicação independente. Nesse sentido, as ações de editar, ler, selecionar e organizar a mensagem são realizadas pelo agente usando a ferramenta cultural correio eletrônico, cuja multifuncionalidade, desterritorialização e virtualidade, integração com outras interfaces, como a de envio e recepção de mensagens, teclado, tela e mouse, produzem no cenário da ação mediada aquilo que chamamos de ambiente de comunicação.

Uma outra propriedade importante da ferramenta cultural é o fato de ela potencializar a transformação da ação mediada (Wertsch, 1998). Assim, quando a ferramenta cultural navegador é usada para selecionar, organizar, apresentar, e buscar informação, essas ações, que eram realizadas por meio de outros meios mediacionais, são transformadas. Na medida em que a integração de meios scripto-áudio-visuais e as aplicações de busca local e remota de palavras-chave são propriedades exclusivas do navegador, ao agente é possivel combiná-las com propósitos prévios ou definir novos propósitos para a ação. Em qualquer um dos casos essas novas qualidades da ferramenta cultural influem com menor ou maior intensidade na ação mediada, a depender entre outros fatores do grau de domínio e apropriação que o agente exerce sobre ela. Tal combinação inusitada de funções e propriedades confere ao navegador a condição de ambiente de informação único com alto potencial para transformar a ação mediada.

A materialidade é uma propriedade inerente a qualquer ferramenta cultural, pois a função de transporte do signo somente se realiza se houver bases materiais para tal. De todos os desdobramentos da integração de meios semióticos, a simulação de modelos é talvez aquele que mais se destaca, devido exatamente à capacidade do navegador, por exemplo, providenciar uma base material para a realização desse tipo de ação. A combinação de registros gráficos, tabelas, movimento de objetos conferem um efeito de realismo ao modelo simulado, que só se materializa na medida em que o agente age com a ferramenta cultural de simulação 
combinando cada uma dessas funções e propriedades. É novamente a combinação inusitada de propriedades e funções que faz da internet um ambiente de simulação, por meio do qual se realizam ações mediadas com valor semiótico potencial para elaborar significado.

Tomando por referência as propriedades da ação mediada, é preciso considerar ainda as implicações do uso das ferramentas culturais da internet sobre as relações de poder e autoridade que se constituem na escola. Nosso argumento centra-se no fato de as ferramentas de autoria e publicação postas à disposição do internauta criarem condições para que sua voz seja alçada para além dos muros escolares. Esta é uma condição que pode alterar substancialmente as relações de poder e autoridade na escola e na sala de aula, se considerarmos que o controle sobre a autoria e a escolha da audiência são prerrogativas de um agente que exerce poder por meio de suas ações e dos instrumentos que tem à sua disposição, conforme indicam, por exemplo, os estudos sobre o surgimento da imprensa na ldade Média (Eisenstein, 1998). É novamente a simbiose de aplicações e de suas propriedades que revela o caráter inovador das diversas ferramentas culturais de autoria da internet. Por meio delas, o agente não apenas edita e dá forma, mas também publica e escolhe o público do seu hipertexto, controlando dessa forma todas as etapas do processo enunciativo, sem precisar se submeter ao crivo de censores. Reunidas, essas funções da ferramenta cultural constituem o ambiente de autoria, que somente tomará parte do cenário para transformar as ações de poder e relações de autoridade na escola, à medida que os agentes dominem e se apropriem da ferramenta de autoria.

Combinadas entre si, as funções e as propriedades das ferramentas culturais produzem ambientes que tomam parte de cenários nos quais se realizam ações mediadas. No caso particular da escola, a combinação desses ambientes suscita a formação de ambiências de ensino e aprendizagem, que serão tão diversificadas quanto forem as finalidades e as formas de combinação. É preciso insistir ainda que tanto as funções das ferramentas quanto as combinações dos ambientes são condicionadas pelos propósitos, os quais orientam os agentes no curso da ação. Mas é também necessário considerar a hipótese de que o domínio e a apropriação das ferramentas culturais da internet pelos agentes e pela escola devem condicionar a estrutura das ações e orientar seus propósitos. Dessa forma, estaremos concentrando nossa análise sobre as ações executadas nos planos externo e interno, procurando identificar quais ferramentas culturais estão sendo empregadas, quem são os agentes que as utilizam, quais propósitos orientam as ações, em quais ambientes e cenários se desenvolvem as ações, no sentido de identificar como a mútua influência de ações internas e externas determina o processo de apropriação das ferramentas culturais pelos agentes e pela instituição. Assim, passaremos a discorrer sobre o cenário no qual se desenvolveram o programa de formação continuada e as investigações, e em seguida especificaremos os procedimentos de análise.

\section{Programa de formação continuada e a coleta de dados}

Com a implantação de uma rede local de computadores em meados de 1998, os professores da Escola Arte-Ofício (EA0) ${ }^{1}$ passaram a ter acesso à internet a partir das salas de áreas $^{2}$ e de um incipiente laboratório de informática. A escola, que está localizada em um campus universitário na cidade de São Paulo, dispõe de boa infra-estrutura física de prédios, com salas de aula reservadas a cada disciplina, laboratórios, horta, e mantém algumas parcerias com departamentos da universidade. A maior parte dos professores tem regime de dedicação integral e ocupam uma posição específica no quadro de carreira da univer-

1.0s nomes da instituição e dos professores foram trocados.

2.0s professores da escola estão organizados em oito áreas: 1ํao $4^{0}$ ano, português, língua estrangeira, arte, educação física, ciências humanas, ciências, e matemática. 
sidade. Eles também costumam participar de programas de formação em serviço, e alguns são pós-graduados.

0 início do desenvolvimento do programa de formação continuada, chamado de Telescola, coincidiu com a implantação da rede local e do acesso da escola à internet e teve como objetivo principal disseminar o uso da internet entre os professores e outros profissionais da área pedagógica. A base do programa de formação constou de um estudo dirigido, cumprido ao longo do semestre letivo com apoio de um tutorial.

Semanalmente, foram realizadas reuniões de tutoria entre professores, ora no papel de alunos, ora no papel de tutores, e pesquisadores. Delas foram extraídas uma parcela das entrevistas informais, chamadas assim devido ao seu caráter não estruturado e por ocorrerem em situações de estudo diante do computador. Mensalmente, os professores e pesquisadores se reuniam para discutir aspectos gerais do programa de formação nas chamadas entrevistas de grupo, e específicos do uso da internet na escola, que devido a caráter semi-estuturado foram chamadas de entrevistas formais, cuja pauta era montada com base em conteúdos temáticos previamente estabelecidos. Ao final de cada semestre, os professores apresentaram suas criações em hipertexto para seus tutores e para os futuros participantes do programa.

A execução do Telescola constou de três fases semestrais consecutivas. Para a primeira fase, foram convidados os professores das áreas de ciências e matemática: duas professoras de biologia, uma de química, um professor e uma professora de matemática. Também durante a primeira fase do projeto, instalou-se uma lista de endereços eletrônicos dos professores e pesquisadores. Esse fórum assincrônico de comunicação serviu prioritariamente ao propósito de organização do trabalho, exposição e resolução de dúvidas, troca de informações e experiências de utilização da rede. Algumas discussões temáticas também foram realizadas.

A realização da segunda fase do Telescola ocorreu de forma similar a da primeira fase, particularmente no que se refere ao estudodirigido. Cada professor-tutor passou a orientar dois professores ${ }^{3}$ e os pesquisadores se retiraram do papel de tutores. Foram organizadas reuniões mensais em grupo, que contaram com a participação dos professores (tutores e aprendizes) e da equipe de pesquisadores. Ainda nessa fase, os professores-tutores e os pesquisadores se reuniam duas vezes por mês para discutir o processo de tutoria. Esse grupo também contou com o apoio de uma lista de discussão específica.

$\mathrm{Na}$ terceira fase, havendo um total de dezessete professores habilitados a orientar, foi possivel estender o programa para todos os professores e demais profissionais interessados. 0 processo de tutoria se desenvolveu de forma similar ao desenvolvido na fase anterior. Nessa fase porém, não houve reuniões face a face do grupo de tutores e pesquisadores; apenas o fórum eletrônico dos tutores permaneceu ativo. As reuniões mensais em grupo foram organizadas em dois períodos, devido à incompatibilidade de horários dos professores. Foram formados quarenta profissionais e apenas quatro professores optaram por não participar.

As entrevistas formais e informais foram registradas em fitas de áudio e as entrevistas em grupo foram registradas em fitas de vídeo, que foram posteriormente transcritas. Na primeira fase foram registradas 39 entrevistas informais, 18 formais e cinco em grupo. Da segunda fase, foram obtidas quatro entrevistas em grupo e foram registradas onze reuniões entre professores-tutores e pesquisadores. Além de oito entrevistas em grupo, a terceira fase produziu também quatro entrevistas semi-estruturadas com professores-tutores. Um grande número de questionários, mensagens dos fóruns eletrônicos e páginas Web também fazem parte do extenso volume de dados coletados entre agosto de 1998 e março de 2000.

Como nossa intenção é identificar nas falas dos professores as evidências de como a elaboração de significados e o domínio e apro-

3. Uma das professoras-tutoras orientou quatro professores. 
priação das ferramentas culturais estão correlacionados, e sobre como esses processos podem explicar a apropriação da internet pela escola, a seleção dos trechos de diálogos (Seqüências 1,2 , e 3) obedeceu em primeiro lugar ao critério de representatividade das situações de estudo dirigido, nas quais os professores interagiram com o tutorial e com os tutores para aprenderem a usar o correio eletrônico. Para segmentar as sessões de estudo dirigido em episódios e estes em seqüências, identificamos atos de fala que indicassem nitidamente fronteiras no movimento discursivo, observando a regularidade do padrão temático e da estrutura discursiva, e adaptando os critérios desenvolvidos por Lemke (1990) na sua análise de aulas de ciências.

0 segundo critério aplica-se ao nosso interesse de examinar mais detidamente os processos de domínio de apropriação da ferramenta cultural pelo professores, pelo qual selecionamos trechos de reuniões em grupo (Extratos 1 e 2, e Seqüência 4), que nos trazem elementos para caracterizar esses processos. Nesse caso, procuramos nos pautar novamente pela representatividade dos diálogos e por uma característica observada recorrentemente nas falas dos professores, o discurso indireto. Por fim, selecionamos um episódio (Seqüência 5) que reúne diversas evidências de um determinado nível de apropriação da internet pela escola, no qual participam todos os professores-tutores e os pesquisadores, já na segunda fase do programa.

A locução, no caso dos extratos, e a cadeia de locuções, no caso das seqüências, são tomadas como unidades de análise. Em todos os casos, as locuções são consideradas nas suas dimensões situacionais, de conteúdo e das interações entre as vozes que habitam o discurso dos professores, valendo-se do princípio de que toda locução é uma resposta a alguma coisa e se orienta para algum interlocutor. A análise considera portanto aspectos estruturais e funcionais das locuções, buscando situá-las no fluxo dos diálogos internos e externos, de modo a identificar as funções da fala, juntamente com as funções de outros sistemas semióticos, na elaboração de significados, e na apropriação e domínio das ferramentas culturais.

No que se refere à codificação das transcrições, o uso de reticências indica a ocorrência de trechos mais longos cujo teor é resumido na análise. Os colchetes são usados para indicar situações de sobreposição de atos de fala e os parênteses descrevem alguma ocorrência significativa para caracterizar a ação. Aspas são usadas para identificar trechos lidos a partir da tela do computador. Extratos e seqüências estão identificados no início pela data e pelo tipo de evento do qual foram retirados. Professores e pesquisadores são identificados por letras e seus nomes foram alterados.

\section{Análise dos episódios}

Os primeiros encontros de tutoria foram importantes para deflagrar a dinâmica das interações do estudo dirigido e nos permitem, portanto, observar como professores-aprendizes e tutores interagiram diante do computador. Passamos então a analisar trechos de diálogos extraídos de episódios de tutoria, que por sua vez constituíram as sessões de estudo-dirigido.

Seqüência 1: Tudo o que a gente viu hoje

+Data: 11/08/98

+Reunião informal.

1. DD: Então olha só, tudo o que a gente viu hoje. Dani?

2. MB: Dani é apelido.

3. DD: É, apelido.

4. MB: Tá.

5. DD: Hydra?

6. MB: É o subdomínio. E aqui é o domínio? (apontando para a tela)

7. DD: lsso. 0 que é hydra?

8. MB: É o provedor.

9. DD: Exatamente. Comercial, br. É isso aí. tá bom?

10. MB: Tá ok. 
A seqüência se inicia com um ato de fala que mobiliza a atenção da professora "então, olha só”, seguido pelo anúncio da revisão do que foi visto. 0 diálogo entre DD e MB se desenvolve dentro de uma modalidade discursiva conhecida como $\mathrm{l}-\mathrm{R}-\mathrm{F}$, na qual 1 corresponde ao início da troca, nesses casos na forma de uma pergunta; $\mathrm{R}$ refere-se à resposta; F ao feedback (Sinclair; Coulthard, 1975; Mehan, 1979). Em todas as três trocas, DD, que é tutora, inicia com perguntas cujas respostas ela já conhece de antemão. Por meio do exemplo de seu próprio endereço eletrônico, a tutora pergunta, valida e corrige as respostas da professora. Portanto, a função dessas triades foi verificar a compreensão dos conceitos discutidos ao longo da sessão de tutoria, na qual professora e tutora negociaram o significado de endereço eletrônico.

Nesse encontro, desenvolveu-se desde o início um estilo de interação assimétrica, na qual a professora, que ora estava aprendendo, ora respondia perguntas e era avaliada pela tutora. A partir dessa seqüência, percebe-se que além das locuções, gestos de indicação também sustentam a interação entre professora e tutora. A indicação, um recurso amplamente observado nas sessões de tutoria, foi mediada tanto pelo gesto de apontar quanto pela seta do mouse. logo após responder a pergunta da tutora, no turno 6, MB pergunta sobre o domínio, apontando para a tela do computador, em um gesto que revela sua atenção ao tutorial e dirige a atenção de ambas para a tela do computador. Em seguida, DD volta a perguntar sobre aquilo que MB já classificara como subdomínio e então obtém uma resposta que lhe satisfaz. A tutora adota, portanto, a estratégia de insistir na pergunta para corrigir a professora. No turno 9, a tutora qualifica o provedor como comercial e ainda se refere ao domínio "br" numa clara alusão ao tutorial. A interação é considerada assimétrica pelo fato de DD e MB estarem de acordo sobre a tutora ser fonte de referência das informações necessári- as para a elaboração do significado de endereço eletrônico. No entanto, a natureza assimétrica da interação não inibe perguntas e antecipações da professora, orientadas pelo tutorial. Esse aspecto aparece em relevo na seqüência 2 .

Seqüência 2: É isso o que vai aparecer

+Data: $11 / 08 / 98$

+ Reunião informal

1. RJ: Tá. Então quando você clicar em nova mensagem, vai aparecer o para.

2. LH: Isso. Você vai digitar aí o endereço.

3. RJ: Tá. 0 clips é o quê?

4. LH: O clips é quando você vai anexar algum arquivo.

5. RJ: Quando vai anexar, tá bom. E esse aqui?

6. LH: Esse daí é o assunto. Você indica pelo assunto. 0 assunto normalmente você coloca uma ... você clica aqui na janelinha do arquivo, aí digita uma palavra que a pessoa vai identificar do que se trata e daí, você clica aqui dentro, na área branca e aí você cria a sua mensagem. 7. RJ: Começa a escrever, tá. "Para. Aqui deve-se preencher com o endereço. Assunto. Pode ou não ser preenchido, mas é interessante que seja notificado a alguém”. E “caixa de texto. Onde você vai escrever". Tudo bem. Aí o encaminhar é que está end.

8. LH: 1sso.

9. RJ: "Depois de tudo pronto, clique no encaminhar. Tela de composição”. (pressiona o mouse e acessa nova tela). "A tela abaixo é a reprodução da tela normal para a composição de mensagens...."

(...)

10. RJ: É isso o que vai aparecer, né?

11. LH: É isso que vai aparecer. Essa é a tela completa, onde você [vai]

12. RJ: [Ah tá, já entendi].

A seqüência 2 é iniciada pela professora RJ com um movimento que direciona a atenção da tutora. Esse ato executa a função de per- 
guntar, na medida em que RJ solicita um juízo sobre sua afirmação. Até o turno 7, observamse três trocas l-R-F, nas quais a professora inicia com perguntas, mas não avalia. Nesse caso, o movimento de feedback das trocas transmite à tutora a informação de que a mensagem foi recebida. Portanto, quem detém o controle da seqüência é a professora orientada pelo tutorial, pois ela direciona suas perguntas à tutora, em conformidade com as informações veiculadas na tela do computador. Em sua resposta mais longa, $\mathrm{LH}$ dirige a atenção da professora para a tela de composição de mensagens, que passa então a ler o tutorial nos turnos 7 e 9 . Nesses turnos, a professora assume o papel de narradora e lê informações que já foram veiculadas nas tríades anteriores. A última frase é lida já em outra página e dirige a atenção da professora para a figura que representa o ambiente de composição de uma mensagem, ou seja a "tela normal para a composição de mensagens”. O efeito de simulação do ambiente de composição, provocado pela figura, é apreendido pela professora, que tem sua percepção confirmada por meio de uma última tríade $\mathrm{l}-\mathrm{R}-\mathrm{F}$.

Nessa interação, observam-se tríades l-R-F invertidas, ou seja, quem está no papel de aprendiz inicia as trocas com perguntas autênticas, cuja função é obter respostas da tutora (Giordan, 2004). Tais perguntas são fruto do diálogo entre a professora e o tutorial, pois elas são claramente orientadas para o entendimento de ícones e palavras que surgem na interação com o tutorial. Durante a leitura, RJ inicia um processo de elaboração de significados apropriando-se da voz do tutorial por meio de um diálogo interno, no qual o encontro entre palavras e imagens é orientado pela voz do tutorial. Esse processo se estende pelas locuções produzidas pela professora, que busca transpor para o diálogo com a tutora as perguntas encetadas na interação com o tutorial, na forma de triades invertidas. Nesse diálogo entre as agentes, reverbera-se a voz do tutorial também na tutora, que se orienta tanto pelas perguntas de RJ como pelas marcações icônicas e imagéticas do tutorial, conforme revelam os termos de indexação "aqui na" e "aqui dentro" no turno 6. Há, portanto, uma orientação explícita de professora e tutora pelos enunciados do tutorial, o qual determina o fluxo dos diálogos.

É em meio a esse encontro de vozes que professora e tutora negociam o significado de correio eletrônico, tramando uma estrutura discursiva na forma de triades, como ocorrera entre MB e DD. Se na segunda seqüência, ao contrário da primeira, a participação da professora é ativa e determina a natureza invertida das tríades, em ambos os casos o movimento discursivo indica que a elaboração de significados está acoplada à apropriação da voz do tutorial, pois à medida que este orienta a atenção das agentes, seja na narração ou na indicação, desenvolve-se um diálogo interno entre cada uma delas e os enunciados do tutorial. Ao mesmo tempo em que opera como fator estrutural da modalidade discursiva, o diálogo interno desempenha uma importante função reguladora no processo de elaboração de significados, sustentando portanto a ação dos agentes com as ferramentas culturais que estão em processo de domínio e apropriação. $\mathrm{Na}$ próxima seqüência, a professora MC executa uma ação mediada pelo correio eletrônico, na qual é possivel observar uma outra situação típica de elaboração de significado.

Seqüência 3: Posso escrever com letra maiúscula?

+Data: 12/08/98

+Reunião informal.

1. MC: Tá bom! Agora assim, aqui para escrever, eu posso escrever com letra maiúscula, minúscula, ou é legal escrever tudo com letra minúscula?

2. NT: Exatamente. Tem os cuidados. É legal você escrever tudo com letra minúscula. Só lógico, o começo das frases, o início do parágrafo com letra maiúscula, o resto minúscula. 3. MC: E o nome da pessoa também? 
4. NT: 1sso, são esses cuidados.

5. MC: Aí pode ir com vírgula?

6. NT: Pode, normal, como se fosse uma carta.

7. MC: Humhum.

8. NT: Fica muito gritante as letras todas em maiúsculas.

9. MC: (digitando mensagem) ponto. Beijos (indicando o final da mensagem). Engraçado, ela mora nos Estados Unidos, eu escrevi pra ela (lendo a mensagem) Pode ficar assim? 10. NT: Pode. Você quer assinar? No final.

11. MC: Aí põe Carolina. Certo?

12. NT: Humhum.

13. MC: Agora eu ponho enviar. Agora eu fecho. Certo?

14. NT: Humhum. Se você tiver mais mensagens para enviar ou para responder, você vai fazendo sempre assim.

15. MC: Tá bom... "Respondendo diretamente a mensagem". Eu respondi. Aí, vem a questão dos cuidados.

Em sua primeira sessão de tutoria, $\mathrm{MC}$ e NT estão diante do computador escrevendo uma "carta" para uma amiga da professora residente em outro pais. Na primeira parte da seqüência, iniciada com o marcador "agora assim" e concluída com o comentário da tutora sobre o efeito gritante das letras todas em maiúsculo, negociase o estilo textual da mensagem eletrônica. Elementos como organização do parágrafo, formato da letra, pontuação, cumprimentos e identidade da missivista são negociados através do diálogo e reunidos em uma "carta", que passa portanto a habitar o horizonte de significados do gênero mensagem eletrônica. Novamente, desenvolve-se a modalidade discursiva 1-R-(F), desta vez, porém, sem a presença explícita de feedbacks. As perguntas de MC têm a função de obter informações sobre a elaboração de uma mensagem eletrônica dirigida a uma pessoa de seu círculo de amizade, e encontra respostas da tutora dirigidas à produção de um texto no formato de uma carta.

A situação de trabalho diante do compu- tador envolve ainda o fato de elas estarem praticando uma atividade do tutorial, cuja finalidade é exatamente escrever uma mensagem eletrônica. Nela, a professora trabalha sobre uma tela real de composição de mensagens, tendo ao fundo uma outra tela do tutorial que exemplifica esse procedimento. No turno 13, logo após enviar a mensagem, ela fecha a tela de sua caixa postal e tem novamente diante de si a tela do tutorial, cujos passos são anunciados no turno 15. A seqüência faz parte, portanto, de uma das atividades do estudo dirigido, que leva a professora a afastar-se do tutorial e orientar-se para a ação de composição de uma mensagem, diferentemente da ação simulada da Seqüência 2. Nesta ação, o diálogo com o tutorial submerge e a professora passa então a interagir com a tutora, que lhe antecipa respostas às questões sobre estilo de composição, que serão apresentadas no próximo passo do tutorial, "a questão dos cuidados". As respostas da tutora atendem às demandas de $\mathrm{MC}$, ao mesmo tempo em que se orientam para o tutorial, servindo portanto como elo entre professora e o tutorial, no fluxo do diálogo produzido entre as agentes e 0 interlocutor virtual.

É nesse movimento de troca de interlocutores que MC passa a agir com a ferramenta cultural correio eletrônico, com a finalidade de se comunicar com uma amiga, ao mesmo tempo em que executa uma tarefa do tutorial. Se nas seqüências 1 e 2 , as professoras dialogavam com o tutorial e com as tutoras, nesta seqüência o ambiente de comunicação é o novo interlocutor direto da professora, com o qual ela inicia o processo de domínio da ferramenta cultural, por meio de ações externas como digitação da mensagem e execução de comandos, e por meio de ações internas como elaboração textual e seleção das opções de comando.

Paralelamente à interlocução com o ambiente de comunicação eletrônica, a professora estabeleceu um diálogo com a tutora e com a amiga distante no espaço, mas próxima no movimento discursivo. Esta proximidade foi provavelmente a razão do sentimento de estranheza anunciado por MC no turno 9. 0 diálo- 
go interno e o diálogo com a tutora orientaram sua elaboração textual no sentido de formar uma concepção sobre o estilo de texto a ser empregado. É na segunda parte da seqüência, iniciada quando a professora passa a digitar a mensagem e encerrada quando ela se prepara para voltar sua atenção ao tutorial, que se tornam visíveis quatro diferentes diálogos da professora. 0 diálogo com a amiga está visivel no turno 9, com a tutora entre os turnos 9 e 15 , com o ambiente de comunicação, nos turnos 9 , 11 e 13, e finalmente com o tutorial no turno 15. Portanto, além dos diálogos com o tutorial e com a tutora, visíveis também nas Seqüências 1 e 2, o processo de elaboração do significado de correio eletrônico conta com mais dois interlocutores, o endereçado e o ambiente de comunicação. Por meio desses diálogos, realizam-se ações internas e externas que, quando estão acopladas, sustentam o processo de domínio da ferramenta cultural.

No extrato abaixo, é possível identificar uma outra situação na qual antigos interlocutores ganharam nova voz e estabeleceram uma interação raramente observada nas escolas.

Extrato 1: Novos meios, novos diálogos

\begin{abstract}
+ Data 28/09/98
+ Reunião de grupo.

RJ: Aí eu falei: ah! Vou mandar um e-mail pra eles! Aí eu mandei um e-mail pra eles, falando que eu achava legal o que eles tavam fazendo ali, que eu não entendia muito bem, que eu não sabia fazer página, mas que eu tinha achado a página que eles tinham feito, tal. E aí, eles me mandaram resposta, tudo: professora $\mathrm{RJ}$, eles devem saber quem eu sou, mas eu não sei exatamente quem são os meninos, né? Então achei bem legal isso. E aí, como é que eles falam? Qualquer problema pode, a gente dá uma força. Alguma coisa assim, né? Então foi legal, achei legal achar a página da escola.
\end{abstract}

0 Extrato 1 é a parte final de uma narrativa, na qual RJ descreve para o grupo de professores e pesquisadores uma das atividades práticas do tutorial, cujo propósito era introduzir alguns sistemas de organização e busca de informações. Em um diretório específico sobre escolas, a professora localizou a página Web da escola que havia sido produzida em caráter experimental por dois alunos. De um modo geral, observa-se que a professora expressa contentamento por ter encontrado a página e também por ter se comunicado com os alunos. Além do relato sobre a atividade prática com sistemas de organização e busca de informações, o elemento mais saliente do ponto de vista da estrutura discursiva é a forma usada por RJ para reportar o diálogo com os alunos.

Nesse discurso citado, a professora cita a si própria para descrever sua atitude ao localizar a página, que foi a de enviar uma mensagem eletrônica, e aos alunos para reportar a resposta deles à sua mensagem eletrônica. Como a maior parte dos discursos orais citados, a locução de RJ é marcada por sua entoação de voz, que distingue as vozes citadas e expressa seu contentamento. No curso da narrativa, ela emprega o discurso citado para analisar sua interação com os alunos, tanto do ponto de vista do conteúdo como da forma pela qual ocorreu a interação. Sobre o conteúdo do diálogo, além de ter expressado satisfação com o trabalho dos alunos, a professora também se referiu à sua falta de conhecimento para produzir uma página Web, mas que mesmo assim, ela conseguira localizar a página. RJ faz perante o grupo uma análise da sua própria condição de aprendiz, dando visibilidade tanto às suas limitações quanto às suas conquistas. Ao citar os alunos, ela destaca aquilo que expressa verdadeiramente uma mudança nas relações entre professora e alunos. Primeiro, o correio eletrônico é capaz de identificá-la perante alunos que ela não conhece diretamente. Segundo, os alunos se colocam à disposição para ajudá-la nas suas dificuldades com a internet. Trata-se de uma interação pouco usual na instituição escolar.

Sobre a forma como ocorre a interação com os alunos, é importante destacar do pon- 
to de vista de nossa argumentação sobre o processo de domínio e apropriação de ferramentas culturais, que a ação de enviar uma mensagem foi executada durante um dos exercícios sugeridos no tutorial, enquanto a professora aplicava-se por si só ao estudo dirigido sobre sistemas de organização e busca de informações. Assim, mesmo tendo sido motivada por fatores internos, a ação de enviar a mensagem aos alunos surgiu em meio a uma ação externa previamente estruturada e dirigida à busca de informações, cujo propósito era diverso desse novo, pelo qual se inicia o diálogo com interlocutores virtualmente desconhecidos, por meio do correio eletrônico. Portanto, é pela interação com o correio eletrônico que a professora transforma o caráter da ação anterior, trocando o ambiente de informação pelo ambiente de comunicação e alterando o propósito da ação mediada. 0 uso do correio eletrônico em uma situação não premeditada sinaliza um novo estágio de RJ no domínio dessa ferramenta cultural, no qual as operações já são realizadas com sucesso e de forma independente, e podem atender a um propósito diverso da ação que vinha sendo executada. Trata-se de um uso autônomo da ferramenta cultural, ainda que suscitada por uma ação decorrente de uma outra ação organizada pelo tutorial.

0 último ato de fala desse extrato, demarcado pelo termo “então", expressa o contentamento da professora sobre ter encontrado a página da escola durante a realização de uma das atividades do tutorial. Ao narrar sua experiência para o grupo de professores e pesquisadores, RJ relatou a comunicação que manteve com os alunos da escola, o que é um forte indício de que sua satisfação tenha resultado dessa troca de mensagens e não simplesmente da localização da página. A intercalação da voz própria e da voz citada para expressar contentamento corrobora essa hipótese. 0 uso do discurso citado não relata apenas o diálogo entre a professora e os alunos, ele também nos indica que o ambiente de comunicação sustentou esse diálogo. Ao empregar essa mo- dalidade discursiva, a professora denunciou sua intimidade com a ferramenta cultural correio eletrônico, o que se torna mais evidente quando se observa que essa referência explícita de uso do correio eletrônico foi feita durante a narração de sua experiência com o uso do ambiente de informação.

Seriam essas as situações típicas que caracterizam a apropriação da ferramenta cultural pelo agente? Nossa análise procura identificar nitidamente em quais situações o agente-usa-a-ferramenta-cultural, de tal modo que a origem dos propósitos da ação e as formas de uso dos ambientes caracterizem o grau de volição do agente sobre a ação. Certamente, seu propósito foi determinado por fatores internos, no entanto, o correio eletrônico foi usado em meio a uma atividade do tutorial, indicando que a estrutura da ação não fora completamente determinada pela professora, mas contou também com a orientação do tutorial. No extrato a seguir, analisamos uma situação na qual identificamos outros elementos que perpassam o processo de domínio do correio eletrônico e nos permite caracterizar um outro estágio de apropriação do correio eletrônico.

Extrato 2: Do telefone ao correio eletrônico

+Data: 04/05/99

+Tipo: Reunião de multiplicadores

MC: Gente, vocês lembram o que eu fiz? Eu marquei, eu organizei o curso na escola, por email. Assim, eu não conhecia a pessoa, no departamento de química. Praticamente foi tudo por e-mail, gente. Assim, acho que eu telefonei uma vez para ela. Primeiro contato foi por telefone, depois foi tudo via e-mail. Depois eu só fui encontrar com ela lá dentro do curso. Você acredita? Então é um exemplo assim de como é uma ferramenta superimportante.

0 extrato 2 faz parte de uma seqüência na qual os professores, agora no papel de tutores, discutem formas de motivação para engajar 
os professores-aprendizes no estudo dirigido. As formas de motivação sugeridas pelo grupo são os exemplos significativos de uso da internet e do computador. Até essa locução, os exemplos tinham se referido às possíveis experiências de interesse dos professores-aprendizes, como por exemplo, obter e organizar informações da internet. Nesse momento, MC usa o vocativo, seguido de uma pergunta, para mobilizar a atenção e evocar a lembrança dos colegas, com o intuito de iniciar uma argumentação que se constrói sobre um relato de experiência. 0 núcleo da argumentação está no fato de ela ter agendado e organizado um curso por meio do correio eletrônico, que é expresso na forma de resposta à sua pergunta retórica. Relato de experiência pessoal é uma modalidade discursiva comumente empregada para trocar informações. No entanto, seu emprego para argumentar sobre a importância da ferramenta revela uma capacidade de discernimento sobre o uso da ferramenta, que só se justifica caso a narradora esteja segura do valor e dos efeitos oriundos das ações executadas por ambas, ferramenta e agente. A modalidade discursiva empregada na situação do diálogo com os pares cumpre uma função retórica de dar visibilidade ao domínio da ferramenta cultural correio eletrônico pela professora.

No seu relato de experiência, a professora empregou o discurso direto para se referir à comunicação com uma convidada, por meio da qual ela agendou e organizou um curso. Ela menciona ter usado dois meios de comunicação antes de encontrar com uma pessoa desconhecida. No primeiro contato, o telefone foi usado e a partir de então, as trocas ocorrem por meio do correio eletrônico. A despeito de essas mensagens serem a principal fonte de dados para se avaliar as mudanças ocorridas no processo de organização de um evento típico da escola, observa-se a partir do relato, que MC usou maciçamente o correio eletrônico para realizar uma atividade colaborativa, que até então não dispensava encontros face a face. É, então, por meio da ferramenta cultural correio eletrônico que a professora dialoga com uma interlocutora externa à escola para planejar uma outra atividade que afeta diretamente sua rotina e a rotina de sua sala de aula. De seu relato é possível também depreender que o uso da ferramenta cultural ocorre de forma completamente desvinculada do tutorial, pelo menos no que diz respeito a qualquer das finalidades do estudo dirigido. Observa-se, portanto, que a estruturação do cenário para a ação de organizar o curso foi determinada pelos propósitos da professora e de sua interlocutora, e também pelo uso autônomo da ferramenta cultural, ou seja, sem recorrer explicitamente à interlocução com o tutorial. Nesse sentido, a substituição de encontros face a face, o planejamento de atividade e a estruturação do ambiente de comunicação com a interlocutora são ações executadas pela professora usando o correio eletrônico que indiciam um estágio avançado de apropriação dessa ferramenta cultural.

Uma das funções mais importantes do correio eletrônico é a possibilidade de enunciação para grupos sociais diversos, o que amplia o potencial dialógico das locuções que circulam por meio dessa ferramenta. Em termos computacionais, essa ampliação se viabiliza por meio de listas de discussão, cujo princípio se traduz na reunião de um conjunto de endereços eletrônicos em um único endereço eletrônico, adicionando tantas outras funções quanto mais se deseje sofisticar o sistema de circulação das mensagens (Giordan, 1998). Assim, o fórum eletrônico de discussão sustenta um encontro assíncrono de vozes, por meio de locuções propagadas em mensagens eletrônicas. É a partir da análise dos relatos dos professores sobre o uso dessa nova modalidade de comunicação, que passamos a identificar os elementos indiciantes do domínio e da apropriação da ferramenta cultural correio eletrônico pela comunidade escolar em estudo. 0 extrato a seguir revela um primeiro estágio desses processos.

Seqüência 4: Porque eu olho, eu leio a lista

+Data: $31 / 08 / 98$

+Reunião de grupo. 
1. RJ: Aí eu ia olhando o JN, eu falava: gente! Esse pessoal está muito avançado.

2. MC: Nem olha, nem olha, esquece.

3. MG: Olhando aonde RJ?

4. RJ: Na lista.

5. MG: Ah! na lista?

6. RJ: Na lista, porque eu olho, eu leio todos os e-mails lá da lista.

7. MG: Tá.

Esta seqüência aparece logo no início da primeira reunião do grupo de professores e pesquisadores na primeira fase do projeto. Nesse momento, RJ está contando para o grupo quais têm sido suas dificuldades com o estudo dirigido e logo após descrever os problemas com a compatibilidade das versões do navegador, ela se refere ao desempenho de seu colega JN.

Ao citar JN, a professora usa o discurso indireto não para se referir a ele, mas a si própria, em uma evidente atitude de análise de uma situação e de seu papel nessa situação. RJ observa JN e compara indiretamente o desempenho do colega com seu próprio desempenho, no que é seguida por $\mathrm{MC}$, que usa da ironia para respaldar sua análise. 0 fator mais expressivo desta seqüência, do ponto de vista do processo de domínio e apropriação da ferramenta cultural correio eletrônico, está no fato de, em sua análise, RJ ter encontrado no correio eletrônico uma ferramenta constituinte do ambiente de comunicação, a qual permite acompanhar ou, nas palavras da professora, olhar e portanto avaliar comparativamente seu desempenho com o de seus colegas. RJ já reconhece uma função estrutural do novo ambiente de comunicação, que é promover os diálogos interno e externo, por meio do encontro de vozes.

0 fato de RJ ler todas as mensagens da lista significa que ela "olha” as locuções e faz desse olhar uma nova forma de sustentar interações, que já não se resumem apenas aos encontros face a face, como nesse em que ela relata seu diálogo interno. RJ nos revela, por meio do discurso citado, ser possível ouvir a voz do outro, por meio de mensagens trocadas por correio eletrônico, e tomá-la como elemento constituinte de seu diálogo interno. Mesmo não sendo visível nesta seqüência, RJ também já usa a ferramenta para enunciar suas locuções e alimentar assim o diálogo com outros agentes. Está posto em relevo, nessa seqüência, um fator que estrutura a elaboração de significados, a interanimação de vozes nos planos interno e externo que é agora mediada por uma ferramenta cultural alicerçada na escrita. Portanto, na internet e no correio eletrônico em particular, as interações para elaborar significados ocorrem por meio de locuções escritas e assincronicamente enunciadas, que encontram no fórum eletrônico um locus para congregar as diferentes vozes que as enunciam.

Até o final da primeira fase do projeto, o fórum eletrônico era usado pelos professores com propósitos majoritariamente relacionados à temática do próprio projeto. Com o início da segunda fase, um outro fórum foi instalado, reunindo desta vez os professores-tutores e os pesquisadores, com o objetivo de estender para o meio eletrônico as discussões sobre o processo de ampliação do uso da internet entre os demais professores e funcionários da escola. $\mathrm{Na}$ seqüência abaixo, extraída de uma reunião entre tutores e pesquisadores, pode-se identificar aquilo que consideramos o principal indicio de apropriação do correio eletrônico pela escola, a instalação do seu próprio fórum eletrônico.

Seqüência 5: Mas gente, é muita lista para participar!

+Data: 30/03/99

+Tipo: Reunião de tutores

1. JN: Agora essas coisas vão diminuir, porque nós, eu estava falando com a Carol né, realmente nós criamos a lista da Escola ArteOfício.

2. RJ: Vocês criaram uma outra lista? fora a lista, ah é !?

3. MC: Agora nós temos três, teleaplica, 
telescola, e ...

4. RJ: Quem está gerenciando?

5. JN: É assim, eu fiz a proposta para a lsaura, escrevi a proposta entreguei para ela, e ela encaminhou para o Mateus para ser criado no Liet, e aí o Liet, o Mateus porque tinha que ter alguém não sei o quê, e me colocou como [gerenciador da lista]

6. RJ: [Mas você vai gerenciar?]

7. MF: Ai que bom.

8. RJ: Então agora a gente já pode, mas gente, é muita lista para participar !

9. JN: [Mas a]

10. MC: [Você viu como você é uma pessoa importante?]

11. JN: Mas que é assim, uma coisa é uma lista ligada a um projeto né? Que você de repente começa a falar de qualquer coisa, vira, perde os objetivos.

12. RJ: É mas essa pode ser uma lista de informes né?

13. JN: Ah! sim, essa vai ser a idéia, que essa lista substitua todos aqueles informes infindáveis que você tem no início.

14. MC: Aí a gente só vai falar assim na reunião, [leia a lista].

15. RJ: [Concordo].

16. JN: Oh! estava lá tal, você leu?

17. MC: Ah! vamos pôr a plaquinha, já imaginou, ganha um pirulito.

18. JN: Eu até coloquei para a Carol, um exemplo de utilização que é superimportante, assim hoje nós temos um conselho, conselho de escola né? Mas não é todo mundo que participa [então]

19. RJ: [Sim], colocar o que aconteceu no conselho.

A Seqüência 5 inicia-se com o professor JN anunciando a criação do fórum eletrônico da escola. Sua locução é decorrente de uma discussão sobre algumas contingências das reuniões gerais do coletivo de professores da escola, particularmente o excesso de informes. 0 anúncio causou euforia entre os professores, o que se verifica na entoação e nos truncamentos das lo- cuções provocados pela sobreposição de atos de fala (indicados por colchetes). 0 fluxo do discurso é basicamente orientado por locuções que visam agregar informações sobre as caracteristicas do novo meio de comunicação da escola, que, segundo os professores, cumprirá uma função complementar às reuniões gerais.

$\mathrm{Na}$ primeira parte da seqüência, RJ e MC estão inicialmente atentas à quantidade de fóruns já criados e logo em seguida o grupo passa a trocar informações sobre nome, endereço eletrônico, participantes e outros detalhes do fórum, os quais foram omitidos da seqüência. 0 motivo da atenção com a quantidade de fóruns se revela no turno 8 , no qual RJ deixa de completar uma idéia para dar vazão à sua preocupação em ter de participar de um número excessivo de fóruns de discussão. Esse ato de fala denuncia uma característica permanente do processo de apropriação de ferramentas culturais, que é o fato de haver sempre resistência de algum tipo (Wertsch, 1998).

Na segunda parte, JN, a pretexto de se identificar como gerente da lista, relata por meio de discurso direto o processo de criação do fórum, dando destaque à interlocução na qual ele, a diretora da escola e o técnico que trabalha nos serviços de informática estão envolvidos. JN legitima sua posição de responsável pelo fórum com base em sua atitude de propor formalmente à direção a abertura do fórum, e também pelo fato de ser necessário alguém ocupar o papel de gerente. Tal legitimidade é reconhecida tanto por MF no turno 7 como por RJ no turno 6, que antecipa a conclusão de JN, sobrepondo-se ao final da narrativa do professor com uma pergunta cuja função é confirmá-lo nesse papel. A pergunta de MC no turno 10 é dirigida a JN também no sentido de respaldá-lo.

Reconhecida a legitimidade, JN passa a responder à preocupação de RJ sobre o excesso de fóruns. A partir desse momento, o grupo se concentra em elaborar os objetivos do novo fórum, por meio da comparação com as situações desencadeadas na reunião geral e por 
meio de um intenso processo de negociação. Inicialmente, JN separa os objetivos dos fóruns do projeto, dos objetivos do fórum da escola que estão em processo de elaboração. Em seguida, RJ propõe a função de circulação de informes para o fórum da escola, no que é aprovada pelo colega, que identifica nessa função uma forma de inibir a prática de relatar os "informes infindáveis". Continuando a comparação com as reuniões gerais, os professores lançam mão do discurso indireto nos turnos 13, 14 e 16 para se referir a si próprios em um diálogo hipotético com seus pares. Essa seqüência, incluindo a ironia do turno 15, responde às críticas sobre as contingências das reuniões gerais e simultaneamente confere ao fórum uma função de difusor de informações. Uma segunda função começa então a ser discutida no turno 18 , onde JN retoma a narrativa para se referir ao conselho de escola e à participação restrita dos professores. RJ identifica pela segunda vez outra função para o fórum que é dar voz ao conselho de escola, provavelmente por meio dos representantes.

A instalação de um fórum eletrônico constitui o primeiro marco do processo de apropriação do correio eletrônico pela escola como instituição. Não apenas como ato isolado, ou simplesmente como a organização de um conjunto de endereços eletrônicos, a instalação do fórum é fruto da iniciativa de uma parte do coletivo dos professores, que encontra respaldo na direção da escola. Os professores, que agora ocupam o papel de tutores, percebem que no uso da ferramenta cultural correio eletrônico está a possibilidade de contornar problemas identificados em situações concretas do cotidiano escolar. Desenha-se também uma separação nítida entre as finalidades dos fóruns de discussão do projeto e desse novo fórum, o que sinaliza para o fato de o uso do correio eletrônico ser decorrente das próprias necessidades da escola e estar, portanto, orientado pelos propósitos das ações desencadeadas dentro da instituição e não mais pelas ações do programa de formação. Reunidos, todos esses elementos indicam que, para a instituição escolar, a ferramenta cultural tem como função viabilizar ações orientadas por seus próprios propósitos que são portanto independentes das ações do programa de formação, o que caracteriza um estágio adiantado de apropriação da ferramenta cultural.

\section{Discussão}

Conforme indicamos na introdução, buscamos com este trabalho compreender as formas como ocorrem o domínio e a apropriação de ferramentais culturais pelos professores e pela escola no curso de um programa de formação continuada. Optamos por analisar situações de estudo dirigido e discussão em grupo, exatamente por elas conferirem visibilidade, no primeiro caso, aos processos individuais de domínio da ferramenta cultural, e, no segundo , por indiciarem os estágios de apropriação em que se encontravam tanto os professores como a escola. Seguiremos essa mesma aproximação para discutir as formas de apropriação do correio eletrônico.

Nas situações de estudo dirigido, verificamos a ocorrência de modalidades discursivas do tipo 1-R-F, que tiveram tanto caráter avaliativo (Seqüência 1), como elicitativo (Seqüências 2 e 3). Nas Seqüências 2 e 3, as triades se caracterizaram por serem invertidas, ao contrário da primeira em que a tutora controlou o fluxo da interação. Além dessas características, os diálogos entre professoras e tutoras desempenharam duas funções principais que caracterizaram as ações realizadas nos cenários do estudo dirigido. Na seqüência 1, o propósito visível é a negociação do significado de endereço eletrônico, o qual está associado à função da triade de verificar o grau de compreensão mútua entre professora e tutora, o que se realiza transmitindo significados por meio das locuções. Mesmo com a troca de papéis entre professora e tutora no controle do fluxo do diálogo, as triades invertidas serviram adequadamente para transmitir significados. A diferença entre essas modali- 
dades está no fato de o fluxo dos diálogos não ser determinado exclusivamente por quem já domina a ferramenta cultural, ao contrário do que tem sido observado nas salas de aula, uma vez que a despeito de quem responde, o teor das respostas indica a intenção do agente em veicular seu juízo de valor sobre o tema em causa. Seguindo o princípio do dualismo funcional sugerido por Lotman (apud Wertsch 1991), é possivel afirmar que uma das funções dos diálogos é obter um grau máximo de univocalidade entre as locuções, o que se cumpre por meio da transmissão de significados pelas locuções.

A segunda função dos diálogos tornase visível quando o terceiro interlocutor ganha voz nas locuções da professora e da tutora, o que denuncia uma outra característica estrutural desse encontro de vozes, a heterogeneidade interna das locuções. Longe de considerar o tutorial como a voz enunciadora do significado compartilhado, ambas agentes travam diálogos com aquilo que Lotman qualificou como “dispositivo de pensamento". Sob esta perspectiva, as locuções não são receptáculos ou condutores passivos, mas funcionam como um gerador e a essência do processo de geração está na interação entre estruturas, o que Lotman comparou a um sistema semiótico em funcionamento (apud Wertsch, 1991). Assim, as "locuções" do tutorial, bem como a das agentes, servem como dispositivos de pensamentos para as interlocutoras quando os diálogos cumprem a função de elaborar significados.

É na interlocução entre a voz do tutorial e a voz da professora que se pode melhor verificar a função dialógica das locuções. Nessas interações, a professora confrontou sua visão de mundo e portanto seus significados sobre a comunicação eletrônica com aqueles veiculados no tutorial, orientando-se pelo objetivo de aprender a usar o correio eletrônico. Para realizar as ações foi preciso que, no início, a professora citasse diretamente o tutorial, como na Seqüência 2, reconhecendo sua autoridade. Em outras situações, como a exemplificada no Extrato 1 , a voz do tutorial já aparece infiltrada à sua locução por meio de citação indireta, quando a professora relata ter dito aos alunos que encontrou a página que eles criaram, sem mencionar como ocorrera a ação. Se pudemos observar a voz dos alunos e a análise feita pela professora naquela citação, tendo como suposto que "a análise é a alma do discurso indireto" (Voloshinov, 1997, p. 159), podemos também ouvir a voz do tutorial reverberando na interação entre professora e alunos, já que a localização de páginas foi uma atividade anunciada pelo tutorial, e distingui-la como uma voz infiltrada na locução da professora. É essa infiltração que nos indica ter havido a interanimação das vozes do tutorial e da professora durante aquela ação.

Por termos considerado atividades práticas na produção do estudo dirigido, pudemos observar a presença dos ambientes da internet em todas as sessões de tutoria, nas quais os próprios professores usaram as ferramentas culturais para realizar as ações. Tenham o navegador, nas Seqüências 1 e 2 , e o correio eletrônico, na Seqüência 3, estado presentes nos cenários das ações, ou tenham eles sido referidos direta e indiretamente nos demais episódios analisados, é fato que esses ambientes mediaram ações concretas como seleção, organização, edição, leitura, e envio de mensagens eletrônicas, bem como busca, leitura, edição e publicação de páginas Web. Para realizar essas ações, conforme também foi relatado nos Extratos 1 e 2, os agentes combinaram as funções e propriedades das ferramentas culturais com o propósito geral de se comunicar com seus interlocutores, sendo, portanto, ferramentas culturais e propósitos, dois elementos determinantes da estrutura das ações. Da mesma forma, ferramentas culturais e propósitos se combinaram às tríades $1-R-F$ e à citação do tutorial, determinando as estruturas dos diálogos e das ações internas.

À luz da proposição do dualismo funcional, as análises dos diálogos extraídos de situações de estudo dirigido diante do computador e de discussões em grupo indicam que tanto a função unívoca, quanto a função 
dialógica das locuções determinaram o fluxo dos diálogos, os quais, por sua vez, sustentaram as ações mediadas por ferramentas culturais e também a elaboração de significados pelos agentes. É nesse sentido que consideramos os processos de domínio e apropriação do correio eletrônico pelos agentes como tendo sido determinados pela co-ocorrência de ações internas e externas, pois a co-ocorrência de ações mediadas pelo diálogo e pelas ferramentas culturais pressupõe a interação de suas estruturas.

Podemos discutir agora as evidências que indiciam o estágio de apropriação do correio eletrônico pela escola no curso do programa de formação continuada. 0 primeiro aspecto a ser considerado é o fato de o programa ter atingido praticamente todos os profissionais envolvidos em atividades pedagógicas. Ainda que a universalização do uso do correio eletrônico pelos indivíduos não explique a apropriação da ferramenta cultural pelo coletivo, o fato de os professores estarem aptos a se comunicar por esse meio é condição necessária para a instalação do fórum eletrônico. Esse é um novo espaço de encontro de vozes, que viabiliza a comunicação "muitos a muitos", estende temporalmente as interações e é capaz de interferir em outras ferramentas culturais já apropriadas pelo coletivo, como a agenda de discussão das reuniões gerais e do conselho de escola.

Da perspectiva da ação mediada, é lícito afirmar que os propósitos de uso do correio eletrônico, suscitados pelo grupo de professores quando se criou o fórum eletrônico da escola, independem das ações de formação continuada e de pesquisa realizadas pelo programa de formação. Os novos propósitos atendem em um primeiro instante às necessidades administrativas e políticas da escola. Posteriormente, com a criação de um fórum sobre prevenção de uso de drogas na escola, a ferramenta cultural também passou a ser usada com finalidades pedagógicas.

Apesar de somente a análise das ações mediadas pelos fóruns da escola poder sustentar a discussão sobre como o correio eletrôni- co interfere na estrutura e nos propósitos dessas ações, podemos afirmar que o processo de apropriação da ferramenta cultural pela escola teve início quando coletivo passou a usar a ferramenta cultural com propósitos próprios da instituição, transformando o caráter das ações que já eram realizadas por meio de outras ferramentas culturais. Antes disso, apenas os indivíduos poderiam ter dominado ou se apropriado do correio eletrônico. A partir da apropriação da ferramenta pela escola, um outro estágio de apropriação é exigido dos professores, que é exatamente o de considerar os propósitos e usos da ferramenta cultural pelo coletivo na realização de suas próprias ações. Nesse sentido, ter observado que o uso do correio eletrônico transformou o caráter das ações mediadas na escola é a principal evidência da apropriação da ferramenta cultural pela instituição.

\section{Implicações}

Diversas pesquisas têm mostrado que para se construir significado na sala de aula é necessário considerar as vozes dos alunos no papel de interlocutores ativos (Coll; Edwards, 1998; De Laplane, 2000; Macedo; Mortimer, 2000). Se por um lado a instalação de uma atmosfera dialógica na sala de aula abre novas perspectivas para o processo de elaboração de significados, por outro, ficamos obrigados a compreender aspectos da forma e da função dos movimentos e modalidades discursivas que se instalam na sala de aula. Dessa maneira, será possivel conceber formas de planejar o ensino considerando a centralidade dos meios mediacionais no processo de aprendizagem, conforme pesquisas recentes têm mostrado (Mortimer; Scott, 2002).

Apesar de a formação dos gêneros discursivos se iniciar e continuar se desenvolvendo fora da sala de aula (Rojo, 1999), é nesse cenário que ocorrem as ações dirigidas para a elaboração de significados que agregam valor científico à visão de mundo dos alunos (Candela, 1998; Wells, 1998). Portanto, se para se conhe- 
cer o mundo, não se pode prescindir da interlocução do aluno com o professor e com os materiais de apoio ao ensino, também não se pode querer cessar sua interlocução com as vozes "estranhas" à sala de aula. Da mesma forma, se pressupomos o diálogo permanente com as comunidades que fazem parte do universo cultural do aluno, é necessário introduzir um nível de interlocução capaz de aproximar as vozes de outras comunidades envolvidas com a construção de significados das culturas científicas. Promover esse encontro de vozes tem se tornado uma tarefa cada vez mais complexa, especialmente por termos à disposição uma grande diversidade de meios de enunciação e estarmos assistindo a uma revolução nesses meios.

Se a internet passa a fazer parte do cenário escolar, é preciso considerar então a forma como ela está sendo introduzida (Lacerda Santos, 2003), na medida em que as novas vozes agregadas à ambiência polifônica irão interferir direta e indiretamente na dinâmica discursiva da sala de aula e portanto na elaboração de significados, pois esta é a marca revolucionária da internet, qual seja, dispor de ambientes nos quais as diferentes vozes se cruzam para transformar as formas de ação da comunidade escolar. Assim, contrariamente àqueles que advogam pela posição dialética entre os campos da informação e comunicação (Belintane, 2002), defendemos a dimensão dialógica de comunicação e elaboração de significados como a principal contribuição a ser criada pelos agentes que se apropriarem desse meio mediacional na escola. 0 que defendemos neste trabalho é que a ida da escola à internet deve tomar como pressuposto a formação de seus professores e da equipe pedagógica dentro da própria escola, o que equivale a considerar em uma primeira fase o movimento de ida da internet à escola.

Como vimos nas seqüências e extratos analisados, diferentes modalidades discursivas sustentam os diálogos que surgem à medida que se desenvolvem ações com o propósito de promover a apropriação da internet pelos professores. Nas situações de tutoria, nas quais o professor ocupa a posição de aprendiz, emergiram tríades avaliativas e elicitativas freqüentemente observadas na sala de aula (Edwards; Westgate, 1994; Mercer, 1998), como "subversões" dessa mesma modalidade (Candela, 1999). Se no papel de aprendizes os professores buscam tomar o controle do fluxo do diálogo, por que então não considerar que os alunos assumam esse papel em determinadas situações da sala de aula? Nesse sentido, as ações desencadeadas em um programa de formação continuada não devem servir apenas para dominar um determinado conteúdo ou alguma ferramenta cultural; são fundamentalmente oportunidades para que o coletivo de professores reflita sobre as formas de aproximação de culturas diferentes, como ocorre na sala de aula, onde o concerto polifônico é um fator determinante da elaboração de significados, tal como se apresentou para eles.

\section{Referências bibliográficas}

BELINTANE, C. Por uma ambiência de formação contínua de professores. Cadernos de Pesquisa, São Paulo, n. 117, p. 177-193. 2002.

BRUNER, J. Vygotsky: a historical and conceptual perspective. In: WERTSCH, J. V. (Ed.). Culture, communication and cognition: vygotskian perspectives. New York: Cambridge Uni Press, 1985. p. 21-34.

BURKE, K. The philosophy of literary form. 3. ed. Berkeley: University California Press, 1973.

. A grammar of motives. Berkeley: University California Press, 1969.

CANDELA, A. A construção discursiva de contextos argumentativos no ensino de ciências. In: COLL, C.; EDWARDS, D. (Org.). Ensino, aprendizagem e discurso em sala de aula. Porto Alegre: Artes Médicas, 1998. p. 143-169.

Student's power in classroom discourse. Lingustics and education, USA. Ablex Publishing Corporation, v.10, n.2, p. 139-163, 1999. 
COLL, C.; EDWARDS, D. (Org.). Ensino, aprendizagem e dsicurso em sala de aula. Porto Alegre: Artes Médicas, 1998.

EDWARDS, A. D.; WESTGATE, D. P. G. Investigating classroom talk. $2^{\text {nd }}$ ed. Bristol, UK: Falmer, 1994.

EISENSTEIN, E. L. A revolução da cultura impressa. São Paulo: Ática, 1998.

GIORDAN, M. Correio e bate-papo: a oralidade e a escrita ontem e hoje. Química Nova na Escola, São Paulo, v.8, p.17-19. 1998.

. Tutoring through the internet: how students and teachers interact to construct meaning. International Journal of Science Education, London, v. 26, n.15, p. 1875-1895, 2004.

LACERDA SANTOS, G. A internet na escola fundamental: sondagem de modos de uso por professores. Educação e Pesquisa, São Paulo, v. 29, n.2, p. 303-312. 2003.

DE LAPLANE, A. L. F. Interação e silêncio na sala de aula. Cadernos Cedes, São Paulo, v. 50, p. 55-69. 2000.

LEMKE, J. L. Talking science: language, learning and values. Norwood, New Jersey: Ablex Pub, 1990.

LOTMAN, Y. M. Text within a text. Soviet Psychology, Rússia, v.26, n.3, p. 32-51, 1988.

MACEDO, M. S. A. N.; MORTIMER, E. F. A dinâmic discursiva na sala de aula e a apropriação da escrita. Educação e Sociedade, Campinas, v. 72, p. 153-173, 2000.

MEHAN, H. Learning Lessons. Cambridge, MA: Harvard Press, 1979.

MERCER, N. As perspectivas socioculturais e o estudo do discurso em sala de aula. In: COLL, C.; EDWARDS, D. (Org.) Ensino, aprendizagem e discurso em sala de aula. Porto Alegre: Artes Médicas, 1998, p. 13-28.

MORTIMER, E. F.; SCOTT, P. Atividade discursiva nas salas de aula de ciências: uma ferramenta sociocultural para analisar e planejar o ensino. Investigações em Ensino de Ciências. Porto Alegre, v.7, n.3. 2002. Disponível em: http://www.if.ufrgs.br/public/ ensino/revista.htm

RAMIREZ, J. D.; WERTSCH, J. V. Retórica e alfabetização: as funções do debate na educação de adultos. In: COLL, C.; EDWARDS,

D. (Org.) Ensino, aprendizagem e discurso em sala de aula. Porto Alegre: Artes Médicas, 1998, p. 201-222.

ROJO, R. H. R. Agir, obedecer e as formas de dizer a ação: as interações familiares na construção das ações, da linguagem e do sujeito social. D.E.L.T.A., São Paulo, v. 15, n. 2, p. 237-267. 1999.

SINCLAIR, J. McH.; COULTHARD, R. M. Towards an analysis of discourse. London: Oxford Univ. Press, 1975.

VOLOSHINOV, V. N. Marxismo e filosofia da linguagem. 8. ed. São Paulo: Hucitec, 1997.

WELLS, G. Da adivinhação à previsão: discurso progressivo no ensino e na aprendizagem de ciências. In: COLL, C.; EDWARDS, D.

(Org.). Ensino, aprendizagem e discurso em sala de aula. Porto Alegre: Artes Médicas, 1998, p. 107-142.

WERTSCH, J. V. Voices of the Mind. Cambridge. EUA: Harvard Uni Press, 1991.

Mind as action. New York: Oxford Uni Press, 1998.

WOOD, D.; BRUNER, J. S. ; ROSS, G. The role of tutoring in problem solving. Journal of Child Psychology and Psychiatry, Londres, v. 17, p. 89-100, 1976.

Recebido em 26.02.04

Modificado em 24.01.05

Aprovado em 10.02.05

Marcelo Giordan é bacharel e doutor em Química. Atualmente é professor do Departamento de Metodologia de Ensino e Educação Comparada da Faculdade de Educação da USP. Realizou programa de pós-doutoramento no Centro de Linguagem e Comunicação na Faculdade de Educação e Esstudos da Linguagem da Open University, no Reino Unido. 


\section{Errata}

Em nosso número anterior (v. 31, n.1), as referêncais bibliográficas do artigo "A Internet vai à escola: domínio e apropriação de ferramentas culturais”, de autoria de Marcelo Giordan, foram publicadas de forma incompleta. Reproduzimos abaixo as referências corretas:

\section{Referências bibliográficas}

BELINTANE, C. Por uma ambiência de formação contínua de professores. Cadernos de Pesquisa, São Paulo, n. 117, p. 177-193. 2002.

BRUNER, J. Vygotsky: a historical and conceptual perspective. In: WERTSCH, J. V. (Ed.). Culture, communication and cognition: vygotskian perspectives. New York: Cambridge Uni Press, 1985. p. 21-34.

BURKE, K. The philosophy of literary form. 3. ed. Berkeley: University California Press, 1973.

A grammar of motives. Berkeley: University California Press, 1969.

CANDELA, A. A construção discursiva de contextos argumentativos no ensino de ciências. In: COLL, C.; EDWARDS, D. (Org.). Ensino, aprendizagem e discurso em sala de aula. Porto Alegre: Artes Médicas, 1998. p. 143-169.

Student's power in classroom discourse. Lingustics and education, USA. Ablex Publishing Corporation, v.10, n.2, p. 139-163, 1999.

COLL, C.; EDWARDS, D. (Org.). Ensino, aprendizagem e dsicurso em sala de aula. Porto Alegre: Artes Médicas, 1998.

EDWARDS, A. D.; WESTGATE, D. P. G. Investigating classroom talk. $2^{\text {nd }}$ ed. Bristol, UK: Falmer, 1994.

EISENSTEIN, E. L. A revolução da cultura impressa. São Paulo: Ática, 1998.

GIORDAN, M. Correio e bate-papo: a oralidade e a escrita ontem e hoje. Química Nova na Escola, São Paulo, v.8, p.17-19. 1998. . Tutoring through the internet: how students and teachers interact to construct meaning. International Journal of Science Education, London, v. 26, n.15, p. 1875-1895, 2004.

LACERDA SANTOS, G. A internet na escola fundamental: sondagem de modos de uso por professores. Educação e Pesquisa, São Paulo, v. 29, n.2, p. 303-312. 2003.

DE LAPLANE, A. L. F. Interação e silêncio na sala de aula. Cadernos Cedes, São Paulo, v. 50, p. 55-69. 2000.

LEMKE, J. L. Talking science: language, learning and values. Norwood, New Jersey: Ablex Pub, 1990.

LOTMAN, Y. M. Text within a text. Soviet Psychology, Rússia, v.26, n.3, p. 32-51, 1988.

MACEDO, M. S. A. N.; MORTIMER, E. F. A dinâmic discursiva na sala de aula e a apropriação da escrita. Educação e Sociedade, Campinas, v. 72, p. 153-173, 2000.

MEHAN, H. Learning Lessons. Cambridge, MA: Harvard Press, 1979.

MERCER, N. As perspectivas socioculturais e o estudo do discurso em sala de aula. In: COLL, C.; EDWARDS, D. (Org.) Ensino, aprendizagem e discurso em sala de aula. Porto Alegre: Artes Médicas, 1998, p. 13-28. 
MORTIMER, E. F.; SCOTT, P. Atividade discursiva nas salas de aula de ciências: uma ferramenta sociocultural para analisar e planejar o ensino. Investigações em Ensino de Ciências. Porto Alegre, v.7, n.3. 2002. Disponível em: http://www.if.ufrgs.br/public/ ensino/revista.htm

RAMIREZ, J. D.; WERTSCH, J. V. Retórica e alfabetização: as funções do debate na educação de adultos. In: COLL, C.; EDWARDS,

D. (Org.) Ensino, aprendizagem e discurso em sala de aula. Porto Alegre: Artes Médicas, 1998, p. 201-222.

ROJO, R. H. R. Agir, obedecer e as formas de dizer a ação: as interações familiares na construção das ações, da linguagem e do sujeito social. D.E.L.T.A., São Paulo, v. 15, n. 2, p. 237-267. 1999.

SINCLAIR, j. McH.; COULTHARD, R. M. Towards an analysis of discourse. London: Oxford Univ. Press, 1975.

VOLOSHINOV, V. N. Marxismo e filosofia da linguagem. 8 ed. São Paulo: Hucitec, 1997.

WELLS, G. Da advinhação à previsão: discurso progressivo no ensino e na aprendizagem de ciências. In: COLL, C.; EDWARDS, D.

(Org.) Ensino, aprendizagem e discurso em sala de aula. Porto Alegre: Artes Médicas, 1998, p. 107-142.

WERTSCH, J. V. Voices of the Mind. Cambridge. EUA: Havard Uni Press, 1991.

Mind as action. New York: Oxford Uni Press, 1998.

WOOD, D.; BRUNER, J. S.: ROSS, G. The role of tutoring in problem solving. Jornal of Child Psychology and Psychiatry. Londres, v. 17, p. $89-100,1976$. 
O arquivo disponível sofreu correções conforme ERRATA publicada no Volume 31 Número 2 da revista. 